\title{
Upaya Meningkatkan Hasil Belajar Siswa Kelas XII Materi Kualitas Gerakan Aktivitas Gerak Ritmik Pelajaran Olah Raga Melalui Model Pembelajaran Talking Stik Pada SMA Negeri 1 Geumpang Kabupaten Pidie
}

\author{
Cut Nur Ishar \\ Guru SMA Negeri 1 Geumpang Kabupaten Pidie
}

\begin{abstract}
Abstrak
Penelitian ini bertujuan untuk meningkatkan hasil belajar olahraga materi kualitas gerakan aktivitas gerak ritmik pada siswa kelas XII SMA Negeri 1 Geumpang dengan menggunakan model pembelajaran Talking Stik Tahun Ajaran 2019/2020. Penelitian ini adalah penelitian tindakan kelas (action research). Subyek penelitian ini adalah siswa kelas XII di SMA Negeri 1 Geumpang yang berjumlah 28 orang. Dari hasil penelitian ini menunjukkan bahwa: melalui penggunaan model pembelajaran talking stik dalam penelitian tindakan kelas pada SMA Negeri 1 Geumpang sudah terjadi peningkatan hasil belajar siswa pada pelajaran olahraga, khususnya materi kualitas gerakan aktivitas gerak ritmik. Sebelum dilakukan pembelajaran dengan menggunakan model pembelajaran Talking Stik ketuntasan siswa adalah 46,43\% dengan rata-rata kelas adalah 54. Pada siklus I hasil evaluasi siswa mendapatkan nilai rata-rata pada pertemuan ke I adalah 60, dan pada pertemuan ke II 60,5 dengan rata-rata kelasnya 60,25 . Sedangkan pada siklus II terus meningkat menjadi rata-ratanya 67,50 pada pertemuan ke 1 dan 78,00 pada pertemuan ke 2 . Dari penelitian tersebut terjadi peningkatan ketuntasan belajar cukup besar dari siklus I ke siklus II sebesar 17,78\%, karena ketuntasan pada siklus I hanya $71,43 \%$, akan tetapi pada siklus II mencapai $989,21 \%$, berarti terdapat peningkatan hasil belajar siswa dan aktivitas proses pembelajaran para siswa setelah dilakukan penelitian tindakan kelas. Dengan demikian, dapat disimpulkan terdapat perbedaan hasil belajar sebelum dan sesudah dilakukan tindakan kelas pada siswa kelas XII SMA Negeri 1 Geumpang.
\end{abstract}

Kata Kunci: Hasil Belajar Melalui Model Pembelajaran Talking Stik

\section{PENDAHULUAN}

Peningkatan kualitas sumber daya manusia melalui pendidikan yang berkualitas. Dalam hal ini, pemerintah telah melaksanakan berbagai program dan menetapkan berbagai kebijakan untuk meningkatkan mutu pendidikan. Pendidikan berintikan interaksi antara pendidik dengan siswa dalam upaya membantu siswa menguasai tujuan-tujuan pendidikan. Menurut Undang-undang No.20 Tahun 2003, pendidikan adalah usaha sadar dan terencana untuk mewujudkan suasana belajar dan proses pembelajaran agar siswa secara aktif mengembangkan potensi dirinya untuk memiliki kekuatan spiritual keagamaan, pengendalian diri, kepribadian, kecerdasan, akhlak mulia, serta keterampilan yang diperlukan dirinya, masyarakat, bangsa dan negara (Hasbullah, 2019:4). Hal ini sejalan dengan pendapat Sapulette dan Wardana dalam Anwar (2017:1) yang mengatakan bahwa pendidikan adalah sebuah wadah untuk membentuk perilaku, potensi dan karakter seseorang unggul dan berkualitas.

Pendidikan dapat dikatakan bermutu apabila terdapat keefektifan dalam proses pembelajaran. Belajar adalah suatu aktivitas atau kegiatan di mana terdapat sebuah proses dari yang tidak tahu menjadi tahu, tidak paham menjadi paham untuk mencapai 
hasil yang optimal. Aktivitas belajar dapat berupa menyampaikan, menelaah, mencari, mengkaji dan meneliti. Hal tersebut menggambarkan betapa pentingnya belajar. Dalam proses pembelajaran aktivitas siswa merupakan hal yang sangat perlu diperhatikan karena pada prinsipnya belajar adalah berbuat, berbuat untuk mengubah tingkah laku yang artinya melakukan sesuatu kegiatan atau aktivitas. Tidak ada belajar kalau tidak ada aktivitas karena tanpa aktivitas proses pembelajaran tidak mungkin berlangsung dengan baik. Itulah sebabnya aktivitas siswa merupakan prinsip atau asas yang sangat penting dalam proses pembelajaran.

Meningkatkan mutu pendidikan melalui peningkatan kualitas proses belajar mengajar juga harus diarahkan kepada peningkatan kemampuan guru yang melibatkan siswa ke dalam kegiatan pembelajaran. Menurut Slameto, guru merupakan sumber utama dalam pembelajaran yang memegang peranan penting dalam pembelajaran (Gintoe, 2015:1). Sedangkan menurut Darmadi, guru memiliki peran penting dalam mengkondisikan lingkungan agar menunjang terjadinya perubahan perilaku bagi siswa (Triana Lestari, 2017:1). Dengan demikian guru diharapkan membuat sedemikian rupa salah satu diantaranya dapat menentukan suatu metode yang sesuai dalam pembelajaran. Pembelajaran yang demikian juga harus diwujudkan dalam mata pelajaran Olahraga. Dalam hal ini pembelajaran Olahraga diharapkan mampu membentuk siswa yang ideal dan memiliki mental.

Namun dalam kenyataannya kemampuan siswa masih rendah, hal ini terbukti masih banyak siswa yang nilai di ujian sekolah kurang dan belum mencapai standar yang telah dietapkan terutama ditingkat Sekolah Menengah Atas (SMA). Sekolah Menengah Atas Negeri 1 Geumpang, yang letaknya di Kabupaten Pidie dengan jumlah gurunya sudah memadai, Menurut pengamatan penulis hanya kelas XII yang kemampuan siswa masing rendah. Salah satu alternatif yang dapat ditempuh untuk meningkatkan hasil belajar siswa adalah melalui kreativitas yang dimiliki guru dalam memilih metode mengajar. Selama ini guru sudah menggunakan metode ceramah bervariasi, tetapi masih banyak siswa yang merasa kesulitan dalam memahami konsep sehingga perlu dicari suatu model pembelajaran yang sesuai dengan kondisi siswa dan kelas tersebut, agar pembelajaran dapat membuat siswa tertarik dan termotivasi.

Pembelajaran kooperatif adalah strategi pembelajaran di mana siswa belajar bersama dalam kelompok-kelompok kecil dan saling membantu satu sama lain. Dalam menyelesaikan tugasnya, setiap anggota kelompok bekerja sama dan membantu untuk memahami suatu bahan pelajaran. Terdapat beberapa tipe pembelajaran kooperatif salah satu diantaranya model pembelajaran Talking Stik, adalah jenis pembelajaran kooperatif dimana siswa belajar berpasangan, sehingga memberi siswa lebih banyak waktu untuk berpikir, merespon dan saling membantu dalam menyelesaikan suatu permasalahan. Anita Lie (2005 : 57) menyebutkan bahwa TPS adalah suatu tipe pembelajaran kooperatif yang cocok diterapkan untuk semua mata pelajaran dan semua tingkat usia anak. Sehingga TPS juga sesuai apabila diterapkan dalam semua mata pelajaran.

Mata pelajaran olah raga adalah mata pelajaran yang membutuhkan ketelitian dan kecermatan. Alternatif penggunaan model pada pembelajaran olah raga diharapkan dapat meningkatkan minat, motivasi dan keaktifan siswa, dengan cara menempatkan siswa belajar secara berkelompok sehingga akan lebih mudah menemukan dan memahami konsep-konsep yang sulit apabila mereka dapat saling mendiskusikan dengan temannya. Dan pada akhirnya hasil belajar siswa pun mengalami peningkatan. 


\section{LANDASAN TEORI \\ Hakikat Pendidikan}

Pada saat dilahirkan manusia sungguhnya telah lengkap baik aspek-aspek yang berkaitan dengan jasmani maupun rohani. Namun kenyataannya, pada saat itu manusia adalah lemah karena aspek yang berkaitan dengan jasmani maupun rohaninya masih bersifat potensial (Soedomo, 2003 : 11). Untuk mencapai kesempurnaan sehingga halhal yang masih potensial dapat berfungsi sebagai mana mestinya, maka diperlukan bantuan, bimbingan dan pengarahan dari orang-orang yang bertanggung jawab. Dengan kata lain manusia perlu diberikan pendidikan.

\section{Komponen Pendidikan}

Umar Tirtarahardja dan La Sulo (2005 : 51) menyatakan bahwa bahwa unsurunsur pendidikan meliputi : subjek yang dibimbing (siswa), orang yang membimbing (pendidik), interaksi antara siswa dengan pendidik (interaksi edukatif), ke arah mana bimbingan ditujukan (tujuan pendidikan), pengaruh yang diberikan dalam bimbingan (materi pendidikan), cara yang digunakan dalam bimbingan (alat dan metode) dan tempat dimana peristiwa bimbingan berlangsung (lingkungan pendidikan).

Tujuan pendidikan merupakan sesuatu yang ingin dicapai melalui kegiatan pendidikan. Penentuan tujuan pendidikan dimulai dari tujuan umum ke tujuan khusus. Adapun tujuan pendidikan menurut Wiji Suwarno (2006 : 33-34) sebagai berikut :

1) Tujuan nasional adalah tujuan pendidikan yang ingin dicapai oleh suatu negara

2) Tujuan institusional adalah tujuan pendidikan yang ingin dicapai suatu lembaga pendidikan

3) Tujuan kurikuler adalah tujuan yang ingin dicapai oleh mata pelajaran tertentu

4) Tujuan instruksional adalah tujuan pendidikan yang ingin dicapai oleh suatu pokok behasan tertentu.

\section{Metode Talking Stik}

Metode pembelajaran ialah alat untuk menggerakkan siswa agar dapat mempelajari pelajaran yang akan dilaksanakan (Hamdayana, 2016:95). Metode pembelajaran didefinisikan sebagai cara yang digunakan guru dalam menjalankan fungsinya dan merupakan alat untuk mencapai tujuan pembelajaran (Uno, 2015:7). Berdasarkan pengertian metode tersebut dapat disimpulkan bahwa metode pembelajaran adalah suatu cara yang dilakukan oleh seorang guru agar tercipta proses belajar siswa untuk mencapai tujuan pembelajaran yang diharapkan.

Menurut Carol Locust, Talking Stick merupakan suatu metode pembelajaran kelompok dengan bantuan tongkat (Huda, 2017:224). Metode Talking Stick adalah metode yang dapat mendorong keberanian siswa untuk mengemukakan pendapatnya (Suprijono, 2017:128). Dari kedua definisi diatas dapat disimpulkan bahwa metode Talking Stick adalah suatu metode dengan bantuan tongkat yang digilir untuk membantu siswa berani mengemukakan pendapatnya. Metode Talking Stick juga dapat dimodifikasi dengan memasukkan musik didalamnya agar pembelajaran semakin aktif dan menyenangkan. Menurut Campbell bahwa mendengarkan musik telah terbukti melambatkan laju denyut jantung, mempertajam pikiran, mengaktifkan gelombanggelombang otak untuk kegiatan berfikir tingkat tinggi dan menciptakan kondisi mental yang positif, santai dan mudah menerima yang ideal untuk belajar (Puspitawangi, 2016:3). 


\section{Langkah-Langkah Model Talking Stick}

1. Guru membentuk kelompok yang terdiri atas 5 orang

2. Guru menyiapkan sebuah tongkat yang panjangnya $20 \mathrm{~cm}$

3. Guru menyampaikan materi pokok yang akan dipelajari, kemudian memberikan kesempatan para kelompok untuk membaca dan mempelajari materi pelajaran

4. Siswa berdiskusi membahas masalah yang terdapat di dalam wacana

5. Setelah kelompok selesai membaca materi pelajaran dan mempelajari isinya, guru mempersilahkan anggota kelompok untuk menutup isi bacaan

6. Guru mengambil tongkat dan memberikan kepada salah satu anggota kelompok, setelah itu guru memberi pertanyaan dan anggota kelompok yang memegang tongkat tersebut harus menjawabnya, demikian seterusnya sampai sebagian besar siswa mendapat bagian untuk menjawab setiap pertanyaan dari guru

7. Siswa lain boleh membantu menjawab pertanyaan jika anggota kelompoknya tidak bisa menjawab pertanyaan

8. Guru memberikan kesimpulan

9. Guru melakukan evaluasi/penilaian, baik secara kelompok maupun individu

10. Guru menutup pembelajaran

\section{Gerakan Aktivitas Gerak Ritmik}

Senam irama atau disebut juga senam ritmik adalah gerakan senam yang dilakukan dengan irama musik, atau latihan bebas yang dilakukan secara berirama. Senam ritmik dapat dilakukan dengan menggunakan alat ataupun tanpa alat. Alat yang sering digunakan adalah gada, simpai, tongkat, bola, pita dan topi. Unsur-unsur yang diperlukan dalan senam irama adalah : kelenturan, keseimbangan, keluwesan, fleksibilitas, kontinuitas, ketepatan, dan gerak koordinasi. Dengan irama siswa perlu menguasai teknik gerakan pada senam irama agar mencapai gerakan yang serasi dan bermanfaat bagi jasmani dan rohani. Hal ini sesuai dengan tujuan senam yaitu membentuk keindahan tubuh, kebugaran dan kekuatan. Ada tiga hal yang harus ditekankan pada senam irama, yaitu :

1. Ketepatan musik/irama

Pada dasarnya irama telah dikenal oleh siswa semasa di Sekolah Menengah Pertama maupun di sekolah dasar, misalnya irama : 2/3, 3/4, 4/4 dan sebagainya. Artinya lagu mempunyai irama $2 / 4$ sebagai berikut, misalnya : tanda irama $2 / 4$ angka 2 mempunyai arti bahwa diantara dua garis berirama dalam lagu tersebut terdapat 2 ketukan/hitungan. Angka 4 atau lengkapnya $1 / 4$ mengandung arti bahwa not itu harganya $1 / 4$ dan mendapat 1 hitungan/ketukan. Dengan begitu hitungan dari irama 2/4 cukup dibunyikan dengan hitungan 1-2, 1-2 dan seterusnya (ditandai oleh tangan dirigen yang hanya naik turun). Ini memungkinkan setiap ketukan ketika menyebut satu dan dua diwakili oleh masing-masing satu langkah.

2. Kelentukan (Fleksibilitas)

Prinsip kelentukan dalam gerakan akan diperoleh berkat latihan yang tekun dan membutuhkan waktu yang cukup lama

3. Kontinuitas Gerakan

Kontinuitas gerakan akan diperoleh dari rangkaian gerak-gerak senam yang telah disusun dalam bentuk rangkaian yang siap ditampilkan. Ini membutuhkan latihan yang tekun dan cukup lama . Maka demi terciptanya keserasian dalam gerak senam irama ketiga hal tersebut harus dikuasai secara matang. Sebelum latihan dengan alat seperti pita, bola, gada, tali dan simpai, terlebih dahulu harus mengenal dan menguasai 
latihan dasar, yaitu : macam-macam langkah, ayunan lengan dan sikap tubuh/posisi tubuh di dalam melakukan latihan.

1) Gerak Ritmik Langkah Kaki

Teknik gerak langkah dalam senam irama sangat penting. Sebab, gerak langkah mendominasi seluruh gerakan dalam senam irama.

$>$ Langkah biasa disebut dengan looppas

$>$ Langkah rapat disebut dengan bijtrekpas

$>$ Langkah depan disebut dengan galoppas

$>$ Langkah samping disebut dengan zijpas

* Gerak dasar loncat

$>$ Loncat ke depan

$>$ Loncat ke samping

$>$ Loncat kijang

$>$ Meloncat sambil membuka dan menutup kaki

2) Gerak Ritmik Ayunan Lengan

Yang harus diperhatikan adalah :

a. Gerak ayun lengan, ayunan besar sesuai arah gerakand an tidak terputus

b. Gerakan mengayun dua lengan, benar sesuai arah gerakan dan ayunan tangan tidak terputus

3) Keseimbangan Gerak Ayunan Lengan dan Kaki

Posisi saat melakukan benar-benar diperhatikan dalam keadaan seimbang antara lengan dan kaki sehingga memudahkan melakukan gerakan berikutnya dan enak untuk dilihat.

4) Kesesuaian Gerak dengan Irama

Musik atau irama yang lazim digunakan untuk mengiringi senam ritmik adalah musik balet. Yaitu sejenis musik klasik, dengan irama ketukan. Untuk menyesuaikan antara musik dengan gerakan senam yang sudh di rancang sedemikian rupa bias sesuai, maka yang perlu diperhatikan :

a. Intro musik (pembukaan) : biasanya terdapat 8 hitungan, atau 2 kali 8 hitungan yang sengaja diciptakan untuk gerakan pendahuluan, misalnya berjalan menuju tempat pembelajaran yaitu area show

b. Musik inti : adalah musik untuk mengiringi gerakan senam ritmik yang dipertunjukkan, dimana bila dilombakan adalah gerakan wajib bagi peserta

c. Musik penutup : walaupun tidak khusus diciptakan sebagai musik penutup gerakan, tetapi siswa harus hafal betul kapan irama akan berhenti, karena hal ini merupakan klimaks dari suatu kebolehan seorang pesenam.

Guna mengatasi hal ini maka seorang pelajar/pesenam harus menjalani program pembelajaran/latihan dengan matang.

\section{METODE PENELITIAN}

Sesuai dengan jenis penelitian yang digunakan yaitu penelitian tindakan kelas atau PTK. Penelitian tindakan kelas yang sering disebut "classroom action research" adalah kegiatan yang dilakukan oleh guru di dalam kelas melalui refleksi diri dengan tujuan memperbaiki kinerjanya sebagai guru, sehingga prestasi belajar meningkat atau tujuan pembelajaran dapat tercapai. Dan bertujuan untuk memperbaiki mutu praktek pembelajaran di dalam kelas. Serta penelitian tindakan kelas ini adalah suatu bentuk penelitian yang dilaksanakan oleh guru untuk memecahkan permasalah nyata yag terjadi di kelas dan meningkatkan kegiatan nyata guru dalam kegiatan pengembangan 
profesinya. Penelitian tindakan kelas ini dilakukan dengan menggunakan model desain model PTK Kemmis S.and Mc. Taggart yang melalui beberapa langkah yaitu perencanaan, pelaksanaan, pengamatan dan refleksi. Keempat langkah tersebut merupakan satu siklus atau putaran dimana sesudah langkah keempat, lalu kembali lagi ke langkah pertama dan seterusnya sampai tujuan dapat tercapai. Penelitian ini terdiri atas 2 siklus. Setiap siklus terdiri atas perencanaan, pelaksanaan dan refleksi

Penelitian dilaksanakan di SMA Negeri 1 Geumpang Kabupaten Pidie selain itu salah satu tujuan yang dari penelitian ini adalah untuk memperbaiki proses pembelajaran mata Olahraga. Penelitian dilaksanakan selama 3 bulan, mulai dari bulan Oktober sampai dengan bulan Desember 2019. Subyek penelitiannya adalah siswa kelas XII SMA Negeri 1 Geumpang Kabupaten Pidie Tahun Pelajaran 2019/2020 yang berjumlah 28 orang siswa.

Sumber data dalam penelitian ini adalah siswa, sebagai subyek penelitian. Data yang dikumpulkan dari siswa meliputi data hasil tes tertulis. Tes tertulis dilaksanakan pada setiap akhir siklus yang terdiri atas Materi macam-macam norma dalam kehidupan. Selain siswa sebagai sumber data, penulis juga menggunakan teman sejawat sesama guru kelas sebagai sumber data. Data yang dikumpukan berupa tes dan observasi. Tes dilakukan pada setiap akhir proses pembelajaran dengan mengguna-kan instrumen soal (tes tertulis) sebanyak 6 atau 10 soal. Penulis menggunakan soal ganda dan essay. Sedangkan observasi yang dilakukan dengan menggunakan lembaran instrumen untuk melihat kegiatan siswa dalam proses pembelajaran diantaranya adalah aktivitas siswa pada saat melakukan diskusi dengan teman dikelompokkan dan diskusi kelas, observasi yang dilakukan oleh guru kolaborasi sebagai observer pada saat belajar mengajar berlangsung.

\section{HASIL PENELITIAN DAN PEMBAHASAN}

Pembelajaran sebelum pelaksanaan tindakan kelas guru mengajar secara konvensional. Guru cenderung mentransper ilmu kepada siswa, sehingga siswa hanya mendengar dan siswa kurang aktif bahkan cenderung bosan, disamping itu dalam penyampaian materi guru tidak menggunakan media pembelajaran. Proses pembelajaran tampak kaku karena siswa hanya melihat dan mendengar apa yang dijelaskan gurunya. Itu semua berdampak pada hasil nilai siswa di kelas XII SMA Negeri 1 Geumpang

Tabel 1. Perolehan Data Hasil Belajar Pra Siklus

\begin{tabular}{|c|l|c|c|c|c|}
\hline No & \multicolumn{1}{|c|}{ Kriteria } & $\begin{array}{c}\text { Jumlah Data } \\
\text { (Rentang Nilai) }\end{array}$ & Jumlah & $\%$ & $\begin{array}{c}\text { Nilai Rata- } \\
\text { Rata Kelas }\end{array}$ \\
\hline 1 & $\begin{array}{l}\text { Sudah mencapai } \\
\text { KKM }\end{array}$ & $65-100$ & 13 orang & $46,43 \%$ & \multirow{2}{*}{54} \\
\cline { 1 - 4 } 2 & $\begin{array}{l}\text { Belum } \\
\text { mencapai KKM }\end{array}$ & $35-64$ & 15 orang & $53,57 \%$ & \multicolumn{1}{|c|}{} \\
\hline
\end{tabular}

Perolehan nilai rata-rata pada kondisi awal (pra siklus) pembelajaran olahraga dapat juga disajikan pada tabel berikut

Tabel 2. Rata-Rata Hasil Tes Pra Siklus

\begin{tabular}{|c|l|c|}
\hline No & \multicolumn{1}{|c|}{ Keterangan } & Nilai \\
\hline 1 & Nilai Tertinggi & 70 \\
\hline 2 & Nilai Terendah & 40 \\
\hline 3 & Jumlah Nilai & 162 \\
\hline 4 & Nilai Rata-Rata & 54 \\
\hline
\end{tabular}


Berdasarkan tabel 1 dan 2 diketahui bahwa pada pra siklus jumlah siswa yang sudah mencapai KKM adalah 13 orang atau $(46,43 \%)$ dan jumlah siswa yang belum mecapai KKM adalah 15 orang $(53,57 \%)$. Dengan nilai tertinggi 70 , nilai terendah 40 dan rata-rata 54.

Perolehan persentase aktivitas guru dan siswa pada tahap awal dalam pembelajaran olahraga dapat dilihat pada tabel di bawah ini :

Tabel 3. Aktivitas Guru dan Siswa Pada Pra Siklus

\begin{tabular}{|c|c|c|c|c|}
\hline No & \multicolumn{2}{|c|}{ Aktivitas Guru } & \multicolumn{2}{c|}{ Aktivitas Siswa } \\
\hline 1 & Nilai & Persentase & Nilai & Persentase \\
\hline 2 & 13 & $45,00 \%$ & 15 & $55,00 \%$ \\
\hline
\end{tabular}

Berdasrakan tabel di atas diketahui bahwa pada pra siklus aktivitas guru sebesar $45 \%$ dan aktivitas siswa sebesar 55\%.

\section{Deskripsi Hasil Penelitian Siklus I}

\section{Tahap Perencanaan}

1) Melihat kurikulum, dan membuat Rencana Pelaksanaan Pembelajaran (terlampir)

2) Menyiapkan alat dan bahan yang akan digunakan

3) Menyusun lembar instrument yang akan digunakan oleh observer sebagai acuan penilaian dan pengamatan tindakan para siswa (terlampir)

\section{Tahapan Pelaksanaan}

Pada tahap ini peneliti melaksanakan pembelajaran sesuai dalam rencana pembelajaran. Peneliti menyampaikan materi berdasarkan urutan langkah-langkah pembelajaran yang sudah disusun dalam RPP yang secara garis besar seperti berikut:

\section{Pertemuan 1}

\section{Kegiatan Awal}

a. Apersepsi. Guru mengembangkan pengetahuan siswa tentang gerak ritmik. Kemudian guru menguraikan dengan jelas gambaran umum mengenai gerak ritmik.

b. Motivasi. Pemahaman mengenai gerak ritmik sangat penting untuk mempermudah pemahaman materi selanjutnya.

\section{Kegiatan Inti}

\section{Eksplorasi}

a. Siswa dapat menjelaskan aktivitas gerak ritmik

\section{Elaborasi}

Dalam kegiatan elaborasi, guru :

a. Siswa dikelompokkan menjadi tiga kelompok (disesuaikan dengan jumlah siswa)

b. Kelompok pertama diberi tugas untuk mencari informasi tentang gerak ritmik

c. Kelompok kedua diberi tugas untuk mempraktekkan gerak ritmik

d. Kelompok ketiga diberi tugas untuk menganalisis aktivitas gerak ritmik

e. Masing-masing kelompok mempresentasikan tugasnya di depan kelas, sedangkan kelompok yang lain menanggapi

f. Dengan bimbingan guru, siswa membuat kesimpulan

\section{Konfirmasi}

Dalam kegiatan konfirmasi, siswa :

a. Menyimpulkan tentang hal-hal yang menyangkut tentang gerak ritmik

b. Menjelaskan tentang hal-hal yang belum diketahui

\section{Kegiatan Akhir}

a. Guru dan siswa melakukan refleksi

b. Penilaian 
Hasil kerja kelompok (kognitif)

- Lembar pengamatan (afektif)

- Lembar pengamatan (psiko motorik)

\section{Pertemuan II}

\section{Kegiatan Awal}

a. Apersepsi. Guru mengembangkan pengetahuan siswa tentang gerak ritmik. Kemudian guru menguraikan dengan jelas gambaran umum mengenai gerak ritmik.

b. Motivasi. Pemahaman mengenai gerak ritmik sangat penting untuk mempermudah pemahaman materi selanjutnya.

\section{Kegiatan Inti}

\section{Eksplorasi}

a. Siswa dapat menjelaskan aktivitas gerak ritmik

\section{Elaborasi}

Dalam kegiatan elaborasi, guru :

a. Siswa dikelompokkan menjadi tiga kelompok (disesuaikan dengan jumlah siswa)

b. Kelompok pertama diberi tugas untuk mencari informasi tentang gerak ritmik

c. Kelompok kedua diberi tugas untuk mempraktekkan gerak ritmik

d. Kelompok ketiga diberi tugas untuk menganalisis aktivitas gerak ritmik

e. Masing-masing kelompok mempresentasikan tugasnya di depan kelas, sedangkan kelompok yang lain menanggapi

f. Dengan bimbingan guru, siswa membuat kesimpulan

\section{Konfirmasi}

Dalam kegiatan konfirmasi, siswa :

a. Menyimpulkan tentang hal-hal yang menyangkut tentang gerak ritmik

b. Menjelaskan tentang hal-hal yang belum diketahui

\section{Kegiatan Akhir}

a. Guru dan siswa melakukan refleksi

b. Penilaian

Hasil kerja kelompok (kognitif)

- Lembar pengamatan (afektif)

- Lembar pengamatan (psiko motorik)

\section{Tahap Observasi dan Monitoring}

Pada tahap ini peneliti bersama observer yang juga teman sejawat menganalisis proses kegiatan pembelajaran dan hasil belajar siswa. Analisis ini dilakukan untuk mengukur sejauh mana tingkat keaktifan, kerja sama dan kreatifitas dalam kegiatan pembelajaran.

Selain itu juga menganalisis kekurangan-kekurangan dan kelebihan peneliti dalam mengajar. Hasil pengamatan terhadap kegiatan siswa selama kegiatan pembelajaran pada siklus I sudah menunjukkan hasil yang lebih baik, artinya terjadi perubahan dalam mengikuti kegiatan pembelajaran dibandingkan dalam kegiatan belajar sebelumnya.

\section{Tahap Refleksi}

Berdasarkan hasil tes pada akhir pembelajaran pertemuan I penulis dapat mengklasifikasikan nilai seperti tabel nilai yang terlampir sesuai dengan nilai tabel di atas penulis dapat menganalisis sebagai berikut :

- Ketuntasan belajar siswa mencapai KKM berjumlah 15 orang atau 53,57\% yang belum tuntas 13 orang 46,43\% dari 28 siswa. Dengan demikian hasil pembelajaran 
yang dicapai pada siklus pertama tatap muka satu, nilai tertinggi 70 dan nilai terrendah 40. Tingkat ketuntasan 60,43\%

- Hasil belajar tatap muka dua penulis melakukan dengan tes atau pengukuran. Pada akhir pembelajaran pertemuan yang ke dua memperoleh hasil sebagai berikut.

- Ketuntasan siswa 50\% dan tidak tuntas 50\%. Nilai tertinggi 75 dan nilai terrendah 45. yang sudah mencapai ketuntasan 15 orang $50 \%$. Setelah di cari rata-rata dari siklus I $62,50 \%$. Nilai dari tingkat ketuntasan 46,43 menjadi $50 \%$.

Berikut hasil belajar pada siklus I dapat diketahui melalui tabel di bawah ini :

Tabel 4. Perolehan Data Ketuntasan Belajar Siklus I

\begin{tabular}{|c|c|c|c|c|c|c|}
\hline \multirow[b]{2}{*}{ No } & \multirow[b]{2}{*}{ Kriteria } & \multirow{2}{*}{$\begin{array}{c}\text { Jumlah } \\
\text { Data } \\
\text { (Rentang } \\
\text { Nilai) } \\
\end{array}$} & \multicolumn{2}{|c|}{ Jumlah Siswa } & \multirow{2}{*}{$\begin{array}{l}\text { Rata- } \\
\text { Rata } \\
\text { Tuntas }\end{array}$} & \multirow{2}{*}{$\begin{array}{l}\text { Nilai } \\
\text { Rata- } \\
\text { Rata } \\
\text { Kelas }\end{array}$} \\
\hline & & & Pert.I & Pert.II & & \\
\hline 1 & $\begin{array}{l}\text { Sudah mencapai } \\
\text { KKM }\end{array}$ & $65-100$ & 18 orang & 20 orang & $71,43 \%$ & \multirow{2}{*}{60,25} \\
\hline 2. & $\begin{array}{l}\text { Belum mencapai } \\
\text { KKM }\end{array}$ & $35-64$ & 10 orang & 8 orang & $32,14 \%$ & \\
\hline
\end{tabular}

Perolehan nilai rata-rata pada siklus I pembelajaran olahraga dapat juga disajikan pada tabel berikut :

Tabel 5. Rata-Rata Hasil Tes Siklus I

\begin{tabular}{|c|l|c|c|c|}
\hline No & Perolehan Nilai & Pertemuan I & Pertemuan II & Rata-Rata \\
\hline 1 & Nilai Tertinggi & 80 & 80 & 80 \\
\hline 2 & Nilai Terendah & 50 & 50 & 50 \\
\hline 3 & Jumlah Nilai & 1680 & 1694 & 1687 \\
\hline 4 & Nilai Rata-Rata & 60 & 60,50 & 60,25 \\
\hline
\end{tabular}

Berdasarkan tabel 4 dan 5 diketahui bahwa pada siklus I jumlah siswa yang sudah mencapai KKM pada pertemuan 1 adalah 18 orang dan pada pertemuan kedua 20 orang dengan persentase rata-rata $71,43 \%$ dan jumlah siswa yang belum mecapai KKM pada pertemuan pertama adalah 10 orang dan pada pertemuan kedua adalah 8 orang dengan persentase rata-rata $32,14 \%$. Dengan nilai tertinggi 80 , nilai terendah 50 dan rata-rata siklus 60,25 .

Perolehan presentase aktivitas guru dan siswa dalam pembelajaran olahraga dapat dilihat pada tabel di bawah ini :

Tabel 6. Aktivitas Guru dan Siswa Pada Siklus I

\begin{tabular}{|c|c|c|c|c|c|c|c|c|c|c|}
\hline No & \multicolumn{5}{|c|}{ Aktivitas Guru } & \multicolumn{5}{|c|}{ Aktivitas Siswa } \\
\hline \multirow{3}{*}{1} & \multicolumn{2}{|c|}{ Pertm.I } & \multicolumn{2}{|c|}{ Pertm.II } & \multirow{2}{*}{$\begin{array}{c}\text { Rata-rata } \\
(\%)\end{array}$} & \multicolumn{2}{|c|}{ Pertm.I } & \multicolumn{2}{|c|}{ Pertm.II } & \multirow{2}{*}{$\begin{array}{l}\text { Rata- } \\
\text { rata (\%) }\end{array}$} \\
\hline & Nilai & $\%$ & Nilai & $\%$ & & Nilai & $\%$ & Nilai & $\%$ & \\
\hline & 14 & 50 & 20 & 71,43 & 61,72 & 18 & 66,66 & 20 & 70 & 68,33 \\
\hline
\end{tabular}

Berdasrakan tabel di atas diketahui bahwa pada siklus I rata-rata aktivitas guru sebesar $61,72 \%$ dan rata-rata aktivitas siswa sebesar $68,33 \%$.

\section{Deskripsi Hasil Penelitian Siklus II}

\section{Tahap Perencanaan}

Pada siklus ini penelitian akan lebih aktif dalam membimbing siswa sehingga dan memotivasi siswa untuk aktif dalam mempelajari materi yang sedang dipelajari dan diharapkan akan terjadi peningkatan hasil belajar siswa dari pada siklus I. Adapun persiapan yang dilakukan peneliti ada siklus II ini adalah mempersiapkan bahan atau materi ajar yang digunakan dalam proses pembelajaran antara lain : 
a. Menyusun Rencana Pelaksanaan Pembelajaran (RPP) sesuai dengan langkahlangkahnya yang sesuai dengan penerapan model pembelajaran talking stik dengan lebih mengaktifkan siswa

b. Menyusun LKS yang akan diselesaikan siswa

c. Menyediakan alat dan bahan yang diperlukan

d. Menyusun kuiz

e. Menyusun soal evaluasi akhir

f. Menyusun lembar instrument aktivitas guru dan siswa tentang penggunaan model pembelajaran talking stik yang akan digunakan oleh observer sebagai acuan penilaian dan pengamatan tindakan guru dan para siswa

g. Peneliti juga meminta 2 orang teman guru untuk menjadi observer

2. Tahap Pelaksanaan

Kegiatan pada tahap ini peneliti melaksanakan pembelajaran sesuai dengan skenario yang telah disusun dalam rencana pembelajaran. Peneliti menyampaikan materi berdasarkan urutan langkah-langkah pembelajaran. Adapun kegiatan yang akan dilakukan pada tahap ini adalah :

\section{Pertemuan 1}

Kegiatan Awal

a. Apersepsi. Guru mengembangkan pengetahuan siswa tentang gerak ritmik. Kemudian guru menguraikan dengan jelas gambaran umum mengenai gerak ritmik.

b. Motivasi. Pemahaman mengenai gerak ritmik sangat penting untuk mempermudah pemahaman materi selanjutnya.

\section{Kegiatan Inti}

Eksplorasi

a. Siswa dapat menjelaskan aktivitas gerak ritmik

\section{Elaborasi}

Dalam kegiatan elaborasi, guru :

a. Siswa dikelompokkan menjadi tiga kelompok (disesuaikan dengan jumlah siswa)

b. Kelompok pertama diberi tugas untuk mencari informasi tentang gerak ritmik

c. Kelompok kedua diberi tugas untuk mempraktekkan gerak ritmik

d. Kelompok ketiga diberi tugas untuk menganalisis aktivitas gerak ritmik

e. Masing-masing kelompok mempresentasikan tugasnya di depan kelas, sedangkan kelompok yang lain menanggapi

f. Dengan bimbingan guru, siswa membuat kesimpulan

\section{Konfirmasi}

Dalam kegiatan konfirmasi, siswa :

a. Menyimpulkan tentang hal-hal yang menyangkut tentang gerak ritmik

b. Menjelaskan tentang hal-hal yang belum diketahui

\section{Kegiatan Akhir}

a. Guru dan siswa melakukan refleksi

b. Penilaian

Hasil kerja kelompok (kognitif)

- Lembar pengamatan (afektif)

- Lembar pengamatan (psiko motorik)

\section{Pertemuan II}

\section{Kegiatan Awal}

a. Apersepsi. Guru mengembangkan pengetahuan siswa tentang gerak ritmik. Kemudian guru menguraikan dengan jelas gambaran umum mengenai gerak ritmik. 
b. Motivasi. Pemahaman mengenai gerak ritmik sangat penting untuk mempermudah pemahaman materi selanjutnya.

\section{Kegiatan Inti}

\section{Eksplorasi}

a. Siswa dapat menjelaskan aktivitas gerak ritmik

\section{Elaborasi}

Dalam kegiatan elaborasi, guru :

a. Siswa dikelompokkan menjadi tiga kelompok (disesuaikan dengan jumlah siswa)

b. Kelompok pertama diberi tugas untuk mencari informasi tentang gerak ritmik

c. Kelompok kedua diberi tugas untuk mempraktekkan gerak ritmik

d. Kelompok ketiga diberi tugas untuk menganalisis aktivitas gerak ritmik

e. Masing-masing kelompok mempresentasikan tugasnya di depan kelas, sedangkan kelompok yang lain menanggapi

f. Dengan bimbingan guru, siswa membuat kesimpulan

\section{Konfirmasi}

Dalam kegiatan konfirmasi, siswa :

a. Menyimpulkan tentang hal-hal yang menyangkut tentang gerak ritmik

b. Menjelaskan tentang hal-hal yang belum diketahui

\section{Kegiatan Akhir}

a. Guru dan siswa melakukan refleksi

b. Penilaian

Hasil kerja kelompok (kognitif)

- Lembar pengamatan (afektif)

- Lembar pengamatan (psiko motorik)

\section{Hasil Observasi}

Pelaksanaan observasi dilakukan oleh teman sejawat selaku pengamat terhadap pelaksanaan pembelajaran yang dilaksanakan oleh penulis, dan aktifitas siswa dalam mengikuti pembelajaran. Hasil observasi siklus II pertemuan I dan pertemuan ke II menunjukkan bahwa pelaksanaan pembelajaran sudah kesesuaian dalam skenario atau rencana. Hasil belajar sudah meningkat secara signifikan hampir seluruh siswa mencapai nilai KKM yang telah ditentukan yaitu 65 .

Tabel 7. Perolehan Data Ketuntasan Belajar Siklus II

\begin{tabular}{|c|l|c|c|c|c|c|}
\hline \multirow{2}{*}{ No } & Kriteria & $\begin{array}{c}\text { Jumlah } \\
\text { Data } \\
\text { (Rentang } \\
\text { Nilai) }\end{array}$ & \multicolumn{2}{|c|}{ Jumlah Siswa } & \multirow{2}{*}{$\begin{array}{c}\text { Rata- } \\
\text { Rata } \\
\text { Tuntas }\end{array}$} & $\begin{array}{c}\text { Nilai } \\
\text { Rata- } \\
\text { Rata } \\
\text { Kelas }\end{array}$ \\
\hline 1 & $\begin{array}{l}\text { Sudah } \\
\text { mencapai } \\
\text { KKM }\end{array}$ & $65-100$ & 24 orang & 26 orang & $89,21 \%$ & \\
\cline { 1 - 2 } 2. & $\begin{array}{l}\text { Belum } \\
\text { mencapai } \\
\text { KKM }\end{array}$ & $35-64$ & 4 orang & 2 orang & $10,79 \%$ & 72,75 \\
\hline
\end{tabular}

Perolehan nilai rata-rata pada siklus II pembelajaran olahraga dapat juga disajikan pada tabel berikut :

Tabel 8. Rata-Rata Hasil Tes Siklus II

\begin{tabular}{|c|c|c|c|c|}
\hline No & Perolehan Nilai & Pertemuan I & Pertemuan II & Rata-Rata \\
\hline 1 & Nilai Tertinggi & 90 & 100 & 95 \\
\hline
\end{tabular}




\begin{tabular}{|c|l|c|c|c|}
\hline 2 & Nilai Terendah & 55 & 55 & 55 \\
\hline 3 & Jumlah Nilai & 2025 & 2340 & 2183 \\
\hline 4 & Nilai Rata-Rata & 67,50 & 78,00 & 72,75 \\
\hline
\end{tabular}

Berdasarkan tabel 7 dan 8 diketahui bahwa pada siklus I jumlah siswa yang sudah mencapai KKM pada pertemuan 1 adalah 24 orang dan pada pertemuan kedua 26 orang dengan persentase rata-rata $89,21 \%$ dan jumlah siswa yang belum mecapai KKM pada pertemuan pertama adalah 4 orang dan pada pertemuan kedua adalah 2 orang dengan persentase rata-rata $10,79 \%$. Dengan nilai tertinggi 90 , nilai terendah 55 dan rata-rata siklus 72,75 .

Perolehan presentase aktivitas guru dan siswa pada tahap awal dalam pembelajaran olahraga dapat dilihat pada tabel di bawah ini :

Tabel 9. Aktivitas Guru dan Siswa Pada Siklus II

\begin{tabular}{|c|c|c|c|c|c|c|c|c|c|c|}
\hline No & \multicolumn{4}{|c|}{ Aktivitas Guru } & \multicolumn{4}{c|}{ Aktivitas Siswa } \\
\hline \multirow{3}{*}{1} & \multicolumn{2}{|c|}{ Pertm.I } & \multicolumn{2}{|c|}{ Pertm.II } & Rata- & \multicolumn{2}{c|}{ Pertm.I } & \multicolumn{2}{|c|}{ Pertm.II } & Rata- \\
\cline { 2 - 10 } & Nilai & $\%$ & Nilai & $\%$ & rata (\%) & Nilai & $\%$ & Nilai & $\%$ & rata (\%) \\
\cline { 2 - 10 } & 24 & 85,57 & 26 & 92,85 & 82,5 & 24 & 85,57 & 26 & 92,85 & 89,21 \\
\hline
\end{tabular}

Berdasrakan tabel di atas diketahui bahwa pada siklus II rata-rata aktivitas guru sebesar $82,5 \%$ dan rata-rata aktivitas siswa sebesar $89,21 \%$.

\section{Refleksi}

Berdasarkan hasil tes pada akhir pembelajaran dua, penulis dapat mengklasifikasikan nilai sebagai berikut.

Siklus II pertemuan I jumlah siswa 28 orang 24 orang siswa yang tuntas $85,71 \%$ sedangkan yang belum tuntas 4 orang siswa 14,29\% telah mencapai KKM yang ditetapkan yaitu 65. Pada siklus II pertemuan II jumlah siswa 28 orang mencapai ketuntasan 26 orang $=92,28 \%$ yang belum mencapai ketuntasan 2 orang siswa $=7,12$ $\%$ nilai tertinggi 100 dan nilai terendah 60 . Dengan demikian hasil pembelajaran yang dicapai pada siklus ke dua, nilai rata-rata 71,75 , persentase ketuntasan siklus II pertemuan I dan II adalah $71,42 \%$ tambah $92,86 \%$ rata-rata ketuntasan pada siklus II = $82,14 \%$.

\section{Kesimpulan}

Setelah melakukan penelitin ini selama dua siklus, maka telah terjadi peningkatan hasil belajar siswa yang cukup baik, berdasarkan hasil penelitian yang telah penulis lakukan, maka dapat disimpulkan bahwa penggunaan model pembelajaran talking stik dapat meningkatkan hasil belajar siswa. Peningkatan tersebut ditandai dengan terjadinya tingkat ketuntasan belajar siswa, dimana ke 20 siswa di kelas XII sudah mencapai nilai tuntas (KKM) yang ditentukan sekolah yaitu 70 .

Berdasarkan paparan hasil penelitian tindakan yang sudah dilakukan selama dua siklus dengan nilai yang didapat para rata-rata hasil evaluasi yang telah dilakukan pada setiap siklus, ternyata terjadi peningkatan yang cukup baik pada setiap siklus yang dilaksanakan dimana pada siklus I diperoleh nilai rata-rata ketuntasan siswa yaitu $71,43 \%$ dengan rata-rata kelas 60,25 dengan tingkat aktivitas siswa 68,33\% dan aktivitas guru mencapai $61,72 \%$. Sedangkan pada siklus II memperoleh nilai rata-rata ketuntasannya 89,21 dengan rata-rata kelas 72,75 dengan tingkat aktivitas siswa $89,21 \%$ dan aktivitas guru $82,5 \%$.

Oleh karena itu penelitian ini dianggap cukup berhasil dan memuaskan bagi peneliti, dimana peneliti dapat mengetahui bahwa: Dengan menggunakan model pembelajaran talking stik dapat meningkatkan pemahaman konsep siswa kualitas 
gerakan aktivitas gerak ritmik di kelas XII SMA Negeri 1 Geumpang Kabupaten Pidie. Hal ini ditandai dengan semakin berkualitas belajar siswa. Pembelajaran dengan menggunakan model pembelajaran talking stik dapat meningkatkan kemampuan siswa mengelompokkan dan membedakan bilangan bulat biasa dan campuran dalam kehidupan sehari-hari.

\section{DAFTAR PUSTAKA}

Anwar, Moh. Khoerul. 2017. Pembelajaran Mendalam Untuk Membentuk Karakter Siswa Sebagai Pembelajar, Universitas Islam Negeri Sunan Kalijaga, Tadris : Jurnal Keguruan Dan Ilmu Tarbiyah Vol.2 No.2 Tahun 2017, h.1

Gintoe, Karnia Yaberdak dkk. 2015. Pengaruh Model Pembelajaran Kooperatif Tipe Talking stick Terhadap Hasil Belajar IPA FISIKA Pada Siswa Kelas VII SMP Negeri 9 PALU, Jurnal Pendidikan Fisika Tadulako (JPFT) Vol.3 No.4 Tahun 2015, h.01

Hamdayana, Jumanta. 2016. Metodologi Pengajaran. Jakarta: Bumi Aksara.

Hasbullah. 2019. Dasar-Dasar Ilmu Pendidikan. Depok: Rajawali Pers.

Huda, Miftahul. 2017. Model-Model Pengajaran Dan Pembelajaran. Yogjakarta: Pustaka Pelajar.

Lie, Anita. 2005. Cooperatif Learning. Jakarta: Gramedia Widiasarana Indonesia.

Puspitawangi, Kadek Rai dkk. 2016. Pengaruh Model Pembelajaran Kooperatif tipe Talking Stick Berbantuan Media Audio terhadap hasil Belajar IPS Siswa, eJournal PGSD Universitas Pendidikan Ganesha Vol.4 No.1 Tahun 2016, h.3

Soedomo, Hadi. 2003. Pengantar Pendidikan. Surakarta: UNS Pers.

Suprijono, Agus. 2017. Cooperative Learning Teori \& Aplikasi PAIKEM. Yogyakarta: Pustaka Pelajar.

Suwarno, Wiji. 2006. Dasar-Dasar Ilmu Pendidikan. Jogjakarta : AR-Ruzz Media.

Trianti Lestari, Ni Ketut. Pengaruh Model Pembelajaran Talking Stick Berbantuan Lagu Daerah Terhadap hasil Belajar IPS, Universtias Pendidikan Ganesha Journal of Education Research and Evaluation, Vol.1 No.4, Tahun 2017, h.01

Uno, Hamzah B. 2015. Belajar Dengan Pendekatan PAIKEM. Jakarta: Bumi Aksara.

Tirtarahardja, Umar, S.L. La Sulo. 2005. Pengantar Pendidikan, Edisi Revisi, Cet. II. Jakarta: Rineka Cipta. 